\title{
Greenland ice sheet monitoring network (GLISN): a seismological approach
}

\author{
Trine Dahl-Jensen, Tine B. Larsen, Peter H. Voss and the GLISN group
}

The dynamics of the large outlet glaciers in Greenland is attracting both scientific and political attention due to the possible implications of a rising global sea level. Extensive glaciological and meteorological monitoring programmes have been implemented to quantify and track changes in the ice sheet and local glaciers (Ahlstrøm et al. 2008). The dynamic processes controlling the flow of the outlet glaciers are complex and poorly understood, involving a wealth of parameters such as bed conditions, hydrology and meteorological conditions. It is desirable to obtain as many fundamentally independent data sets as possible to understand and eventually predict the behaviour of the outlet glaciers.

Some processes related to ice dynamics can be detected seismologically and thus completely independently from classical ice-monitoring techniques, such as satellite remote sensing, global positioning system (GPS) geodesy and automatic weather stations. Detectable cryo-seismological events include high-frequency ice quakes (Anandakrishnan \& Bentley 1993; Harrison et al. 1993), calving events (O’Neel et al. 2006; Nettles et al. 2008) and less well understood processes such as low-frequency glacial earthquakes (Ekstrom et al. 2003; Nettles et al. 2008)) and glacial rumblings (Rial et al. 2009). Changes in ice load along the margin of the ice sheet can lead to earthquakes from glacial rebound, and earthquakes can provide an independent constraint on ice mass redistribution (Johnston 1987; Stewart et al. 2000; Lund \& Näslund 2009).

The Greenland ice sheet monitoring network (GLISN) project will monitor changes in glacier dynamics using a large broadband seismological network. The network will also improve the detection of tectonic earthquakes in Greenland, thereby establishing a better baseline for local seismicity. The baseline will allow detection of future changes in seismicity caused by changes in ice load. It is the objective of the project to contribute significantly to understanding the dynamics of the Greenland ice sheet and glaciers by studying cryo-seismological processes.

Installing and operating a large real-time seismological network in Greenland is logistically complicated and expensive. An international team consisting of researchers from 10 institutions in 8 countries in Europe, North America and Asia are working together to meet this challenge (Fig. 1).

\section{Glacial earthquakes and rumblings}

Cryo-seismological events such as glacial earthquakes and rumblings can be linked to large-scale glacier dynamics. Glacial earthquakes are produced at large outlet glaciers and appear to be associated with large calving events (Amundson $e t$ al. 2008; Nettles et al. 2008). However, the processes leading

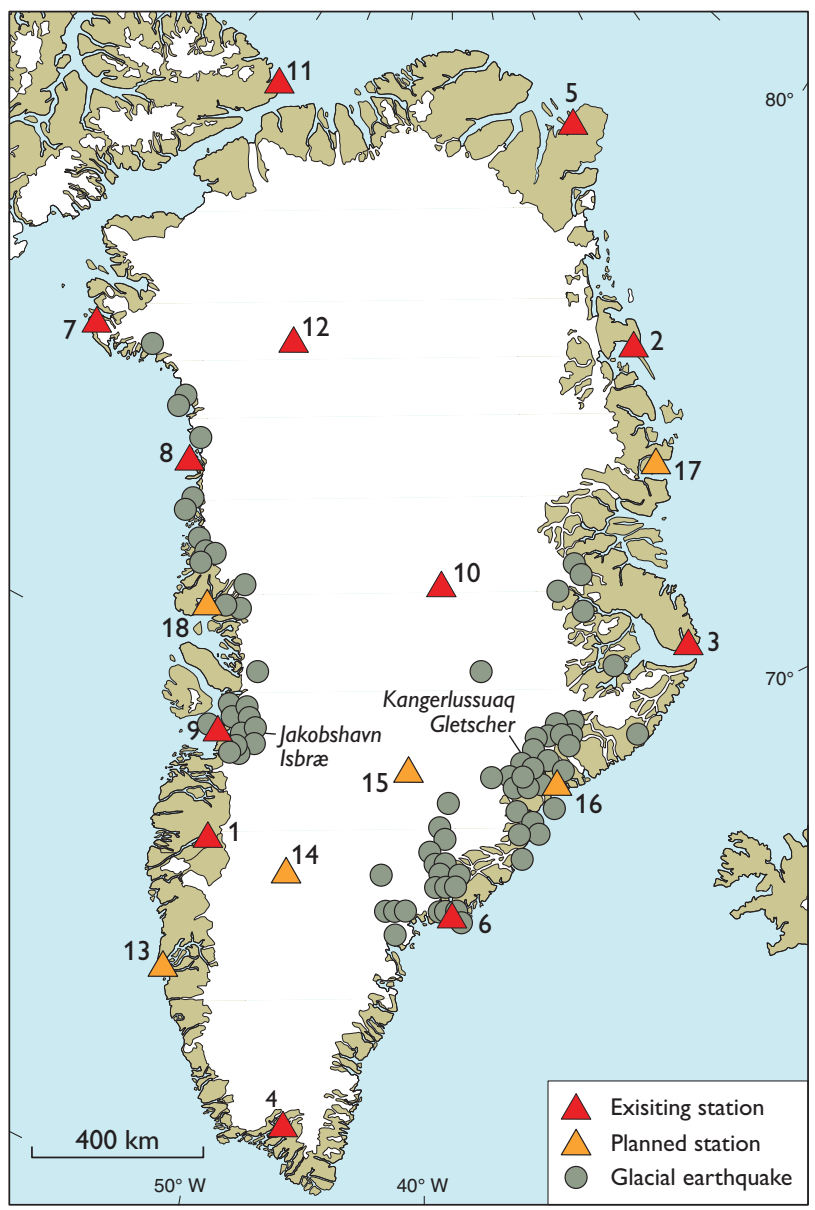

Fig. 1. Map of broadband seismographs in Greenland. 1-4: permanent stations operated by GEUS in cooperation with other institutions. 5-7: long-term stations maintained by GEUS. 8-9: new GLISN long-term stations run by ETH (Switzerland). 10: a long-term station run by GEOFON (Germany). 11: a permanent station at Alert in Canada run by IRIS (USA). 12: a temporary station run by GEUS. 13-18: planned and funded new GLISN stations to be installed by IRIS and ETH. 
to a glacial earthquake are still poorly understood, as are the changes in dynamics following an earthquake.

Glacial earthquakes are slow, low-frequency events that can be detected on seismographs worldwide. The vast majority of glacial earthquakes in Greenland occur at the large outlet glaciers in western and eastern Greenland (Fig. 1; Ekstrom et al. 2003). During a period with warmer than average temperatures in Greenland, a sharp increase in the number of glacial earthquakes has been observed (Ekstrom et al. 2006); during the same period there was no change in the number of observed tectonic earthquakes.

The glacial earthquakes can be registered at teleseismic distances, and the teleseismic signals are sufficiently strong to locate the earthquakes. However, the signals from glacial earthquakes are fundamentally different from the signals generated by tectonic earthquakes. The short-period signal from a 4.9 magnitude glacial earthquake is barely discernable on seismograms $c .1000 \mathrm{~km}$ away as shown in Fig. 2A. The data record has been filtered from 0.5 to $1.3 \mathrm{sec}$ where $P$ (primary) waves normally dominate the seismogram. Close to the

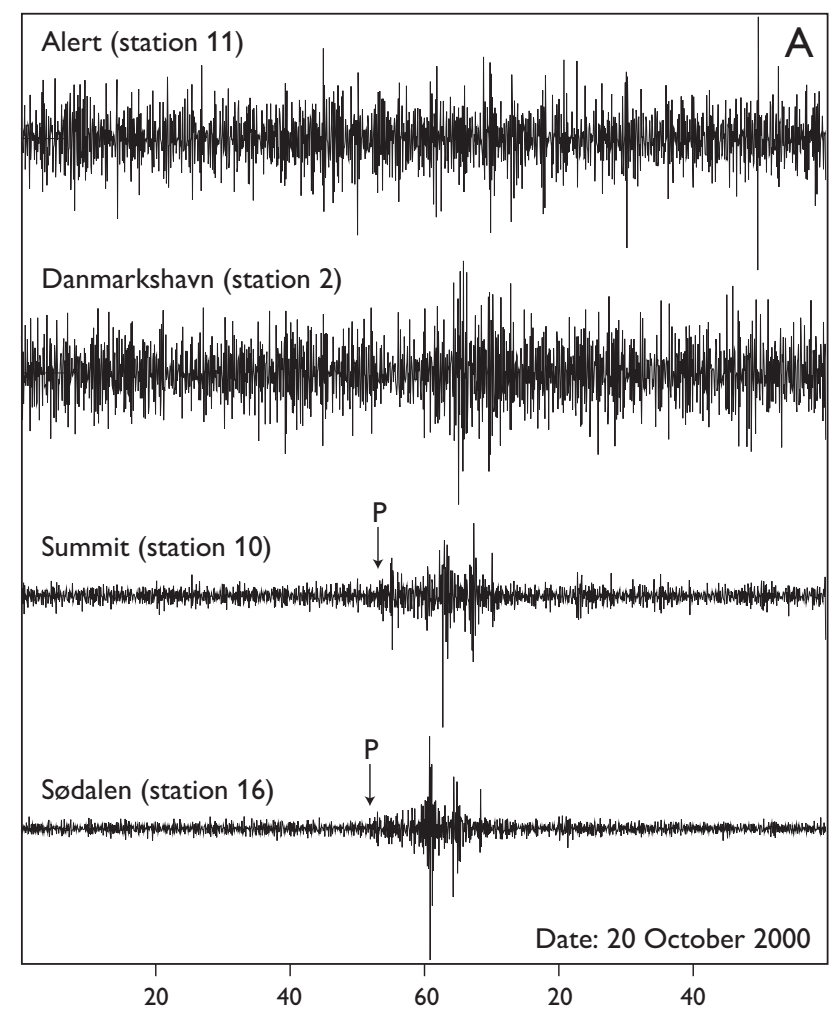

epicentre of a glacial earthquake, the $P$ wave is clearly visible (at Sødalen and Summit; Fig. 2A), whereas it requires supporting stations to identify the signal at Danmarkshavn approximately $974 \mathrm{~km}$ away and the short-period signal is completely lost at Alert $1645 \mathrm{~km}$ away. For a tectonic earthquake of similar magnitude, the short-period $P$ wave can travel many thousands of kilometres without being dissipated below the noise level. The longer periods in the signal from a glacial earthquake are not dissipated as rapidly as the shorter periods (Fig. 2B) and retain a good quality at teleseismic distances.

The higher-frequency waves generated by a glacial earthquake contain information about processes in and around the glacier during the earthquake. In order to understand the earthquake processes it is necessary to model waveforms recorded at local and regional distances where the full frequency range is retained. This is currently only possible for a small portion of the glacial earthquakes occurring in Green-

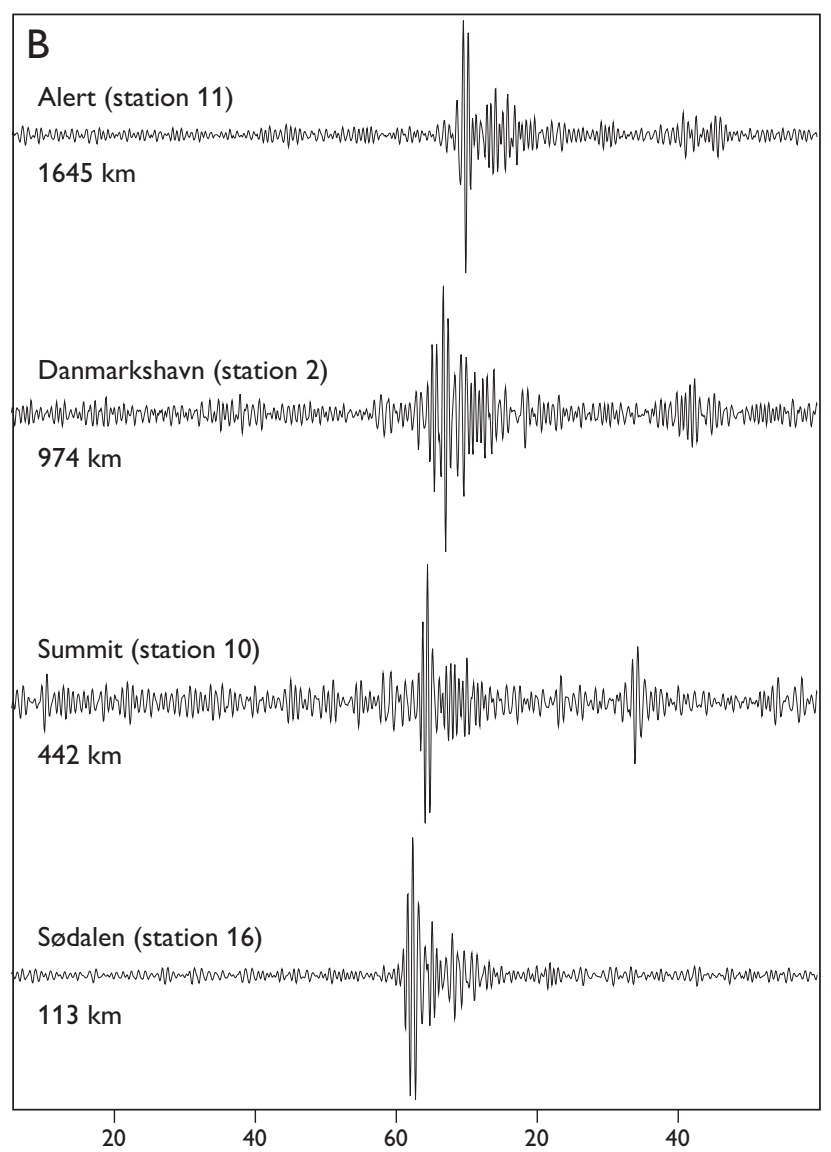

Fig. 2. A large glacial earthquake released by the Kangerlussuaq Gletscher (Fig. 1). The window shows 2 hours of data from four broadband seismographs in Greenland and Canada, located $113-1645 \mathrm{~km}$ from the earthquake. Station numbers refer to Fig. 1. The curves show vertical components band-pass filtered from $0.769-2.000 \mathrm{~Hz}(\mathbf{A})$ and $0.01-0.03 \mathrm{~Hz}(\mathbf{B})$. The glacial earthquake was registered from $c .02: 00-02: 15$ UTC and had a magnitude of 4.9 on the Richter scale according to Ekstrom $e$ t al. 2003. In $\mathbf{A}$ the arrival of the $P$ wave is marked by arrows on the two closest stations (Summit and Sødalen). The arrival of the $P$ wave is commonly only visible at higher frequencies and at stations close by. The data from Sødalen are from a station that was in operation from 2000 to 2002 . 
land, but with the implementation of the GLISN network the glacial earthquakes can be investigated in greater detail than today.

Glacial rumblings are slow, high-frequency events at the large outlet glaciers, and also appear to be related to calving that can be detected only at local to regional distances (Fig. 3). Rumblings have so far been described in only one publication for the Jakobshavn Isbrx (Rial et al. 2009), but can be found in data from other regions of Greenland as well. It has been postulated that up to $30 \%$ of the annual iceberg discharge from Jakobshavn Isbræ can be related to rumblings that are registered on seismographs (Rial et al. 2009), but it has not yet been possible to make a similar estimate for the glacial earthquakes.

The GLISN project will establish and run a dense network that can capture events both at currently seismologically active glaciers and at glaciers farther to the north should the activity migrate northwards. The seismological signals may provide an early warning of changes in glacier activity.

\section{Establishing the network}

The aim of the GLISN project is to cover all of Greenland and surrounding areas with as regular a seismological network as feasible (Fig. 1). The stations will be upgraded to a common standard and will provide real-time data online. Stations situated in Greenland communities will transmit data by ADSL broadband, while data from the remote stations will be transmitted by satellite, using the Iridium system. New sites are chosen to cover areas close to sites where glacial seismological events are known to occur, and to ensure monitoring of the whole of Greenland, so that changes in occurrence patterns such as a northwards shift can be detected. The main challenge is the operation of stations in remote areas, not least those on the Greenland ice sheet. Two sites on the ice sheet (sites 12 and 14; Fig. 1) will be equipped with surface seismographs dug into the snow. Since these are quite sensitive to settling snow and loss of levelling, these sites will also be equipped with seismographs in $300 \mathrm{~m}$ deep boreholes, in which the seismograph is fixed to ice instead of snow making it more stable. The network upgrade and installation were initiated in 2009, and are planned to be completed in 2011.

\section{International cooperation}

GLISN is an international cooperation between Incorporated Research Institutions for Seismology (IRIS) in the USA, Geological Survey of Denmark and Greenland (GEUS), GeoForschungsZentrum Network (GEOFON) in Germany, ETH Zürich in Switzerland, Istituto Nazionale di Geofisica e Vul-

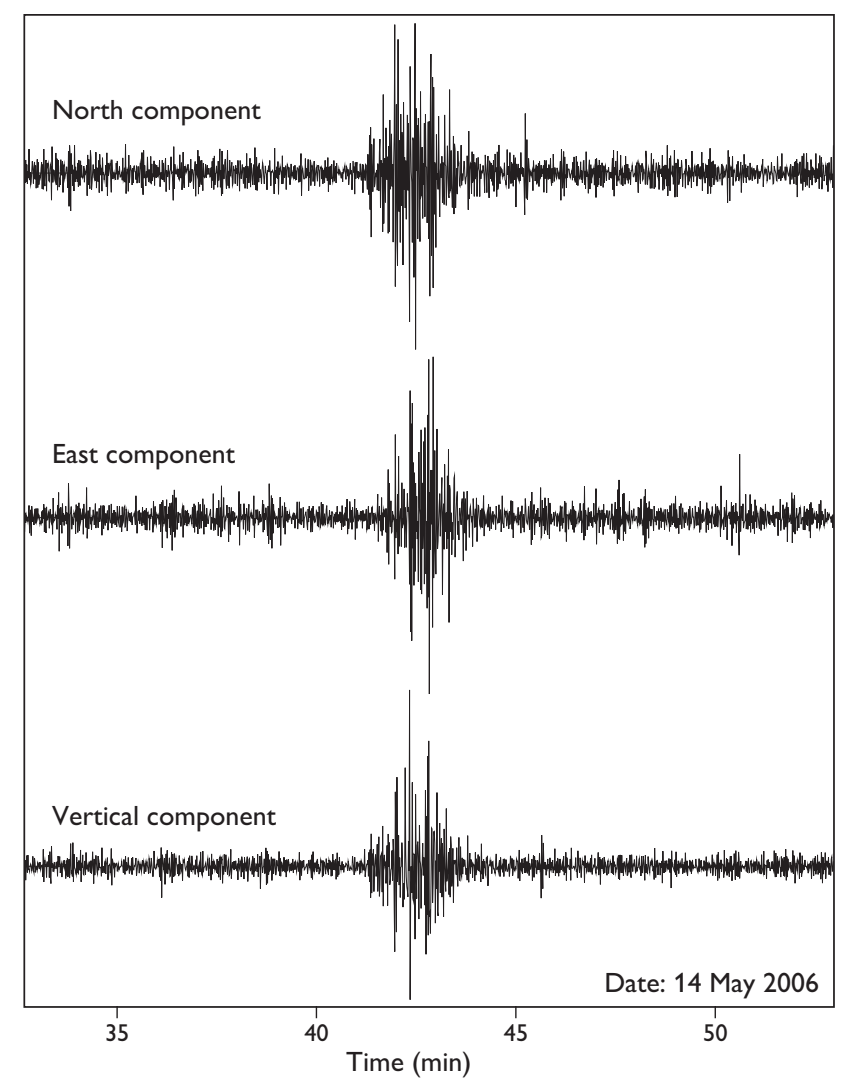

Fig. 3. Rumbling from Jakobshavn Isbræ observed on the broadband seismograph at station 1 (Fig. 1). The window shows 20 minutes of seismic data that have been band-pass filtered from 5 to $9.9 \mathrm{~Hz}$. The glacier rumbling was observed from $c .12: 41$ to 12:44 UTC and is described by Rial $e t$ al. 2009. On our local scale the event was of magnitude 2.1.

canologia (INGV) in Italy, National Institute of Polar Research (NIPR) and Japan Agency for Marine-Earth Science and Technology (JAMSTEC) both in Japan, NORSAR in Norway and Geological Survey of Canada (GSC). The group is open and other participants are welcome.

The operation of broadband stations in Greenland builds on work by GEUS (Dahl-Jensen et al. 2003). The contribution from GEUS to establish GLISN is the existing network, consisting of four permanent and four temporary stations, which has been in operation for up to a decade. Since 2002, our German colleagues have operated the only long-term station on the ice sheet at Summit Camp (station 10, Fig. 1), which is now also part of GLISN. Our Swiss colleagues installed two new GLISN stations in north-western Greenland in 2009 and will add one more in 2010. Furthermore, our colleagues from the USA have obtained a three-year grant from the National Science Foundation, providing the bulk of the funding for the project. This grant allows installation of five new stations and upgrading of the existing stations to 
meet the technical standards for equipment and installation agreed for GLISN - including provision of real-time data.

\section{Expected outcome}

With GLISN we seek to increase our understanding of the processes governing the ice sheet and the dynamics of the outlet glaciers. The complex processes and dynamics must be studied from different angles, such as satellite data acquisition and geodetic and glaciological observations. Seismology, and thus the ability to detect events deep within and below the ice, is a new player in this field, raising many new questions.

Local seismicity in Greenland has not been addressed in detail for many years (Gregersen 1989; Dahl-Jensen 1984). However, increasingly detailed data have been gathered since 2000 (Dahl-Jensen et al. 2003) and data acquisition is rapidly increasing after the inauguration of GLISN. The pressure from ice sheets usually dampens earthquakes beneath the ice (Johnston 1987; Stewart et al. 2000; Lund \& Näslund 2009). If the ice sheet thins and retreats in the future, the frequency of earthquakes related to glacial rebound will probably increase. Seismology is thus a tool to detect changes in the pressure on the subsurface due to climate changes.

GLISN also allows the continuation and expansion of the use of tectonic earthquakes to investigate the structure of the Greenland crust, lithosphere and upper mantle in increasing detail (Dahl-Jensen et al. 2003; Darbyshire et al. 2004; Kumar et al. 2005, 2007; Larsen et al. 2006; Ucisik et al. 2008).

\section{Acknowledgements}

The entire GLISN group forms the backbone of GLISN. The website www.glisn.info provides additional information on contributions and funding.

\section{References}

Ahlstrøm, A.P. \& the Promice project team 2008: A new programme for monitoring the mass loss of the Greenland ice sheet. Geological Survey of Denmark and Greenland Bulletin 15, 61-64.

Amundson, J.M., Truffer, M., Lüthi, M.P., Fahnestock, M., West, M. \& Motyka, R.J. 2008: Glacier, fjord, and seismic response to recent large calving events, Jakobshavn Isbræ, Greenland. Geophysical Research Letters 35, L22501, doi:10.1029/2008GL035281.

Anandakrishnan, S. \& Bentley, C.R. 1993: Micro-earthquakes beneath Ice Streams B and C, West Antarctica: observations and implications. Journal of Glaciology 39, 455-462.
Dahl-Jensen, T. 1984: Jordskælv og skorpestruktur i Grønland, 73 pp. Unpublished M.Sc. thesis, Københavns Universitet, Danmark.

Dahl-Jensen, T., Larsen, T., Wölbern, I., Bach, T., Hanka, W., Kind, R., Gregersen, S., Mosegaard, K., Voss, P. \& Gudmundsson, O. 2003: Depth to Moho in Greenland: receiver function analysis suggests two Proterozoic blocks in Greenland. Earth and Planetary Science Letters 205, 379-393.

Darbyshire, F.A., Larsen, T.B., Mosegaard, K., Dahl-Jensen, T., Gudmundsson, O., Bach, T., Gregersen, S., Pedersen, H. \& Hanka, W. 2004: A first detailed look at the Greenland lithosphere and upper mantle using Rayleigh wave tomography. Geophysical Journal International 158, 267-286.

Ekstrom, G., Nettles, M. \& Abers, G.A. 2003: Glacial earthquakes. Science 302, 622-624.

Ekstrom, G., Nettles, M. \& Tsai, V.C. 2006: Seasonality and increasing frequency of Greenland glacial earthquakes. Science 311, 1756-1758.

Gregersen, S. 1989: The seismicity of Greenland. In: Gregersen, S. \& Basham, P.W. (eds): Earthquakes at North-Atlantic passive margins: Neotectonics and postglacial rebound, 345-353. Berlin: Springer.

Harrison, W., Echelmeyer, K. A. \& Engelhardt, H. 1993: Short-period observations of speed, strain and seismicity on Ice Stream B, Antarctica. Journal of Glaciology 39, 463-470.

Johnston, A.C. 1987: Suppression of earthquakes by large continental ice sheets. Nature 330, 467-469.

Kumar, P. et al. 2005: The lithosphere-asthenosphere boundary in the North-West Atlantic region. Earth and Planetary Science Letters 236, 249-257.

Kumar, P., Kind, R., Priestley, K. \& Dahl-Jensen, T. 2007: Crustal structure of Iceland and Greenland from receiver function studies. Journal of Geophysical Research 112, B03301.1-B03301.19.

Larsen, T.B., Dahl-Jensen, T., Voss, P., Jørgensen, T.M., Gregersen, S. \& Rasmussen, H.P. 2006: Earthquake seismology in Greenland - improved data with multiple applications. Geological Survey of Denmark and Greenland Bulletin 10,57-60.

Lund, B. \& Näslund, J.-O. 2009: Glacial isostatic adjustment: implications for glacially induced faulting and nuclear waste repositories. In: Connor, C.B., Chapman, N.A. \& Connor, L.J. (eds): Volcanic and tectonic hazard assessment for nuclear facilities, 142-155. Cambridge: Cambridge University Press.

Nettles, M.etal.2008: Step-wise changesinglacier flow speed coincide with calving and glacial earthquakes at Helheim Glacier, Greenland. Geophysical Research Letters 35, L24503, doi:10.1029/2008GL036127.

O’Neel, S., Mcnamara, D., Marshall, H. \& Pfeffer, T. 2006: Seismic evidence for time variation of mechanical failure associated with iceberg calving at Columbia Glacier, AK. EOS Transactions, American Geophysical Union, 87(52), 1719 only.

Rial, J.A., Tang, C. \& Steffen, K. 2009: Glacial rumblings from Jakobshavn ice stream, Greenland. Journal of Glaciology 55, 389-399.

Stewart, I.S., Sauber, J. \& Rose, J. 2000: Glacio-seismotectonics: ice sheets, crustal deformation and seismicity. Quaternary Science Reviews 19, 1367-1389.

Ucisik, N., Gudmundsson, O., Hanka, W., Dahl-Jensen, T., Mosegaard, K. \& Priestley, K. 2008: Variations of shear-wave splitting in Greenland: mantle anisotropy and possible impact of the Iceland plume. Tectonophysics $462,137-148$.

\footnotetext{
Authors' address

Geological Survey of Denmark and Greenland, Øster Voldgade 10, DK-1350 Copenhagen K, Denmark. E-mail: tdj@geus.dk
} 